Article

\title{
The In Vivo and In Vitro Toxicokinetics of Citreoviridin Extracted from Penicillium citreonigrum
}

\author{
Yosuke Uchiyama ${ }^{1}$, Masahiko Takino ${ }^{2}$, Michiko Noguchi ${ }^{3}$, Nozomi Shiratori ${ }^{1}$, \\ Naoki Kobayashi ${ }^{1}$ and Yoshiko Sugita-Konishi ${ }^{1, *}$ \\ 1 The Graduate School of Life and Environmental Sciences, Department of Food and Life Sciences, \\ Azabu University, 1-17-71 Fuchinobe, Chuo-ku, Sagamihara-shi, Kanagawa 252-5201, Japan; \\ de1701@azabu-u.ac.jp (Y.U.); shiratorin@aqua-ckc.co.jp (N.S.); n-kobayashi@azabu-u.ac.jp (N.K.) \\ 2 Agilent Technologies, Japan, Ltd., 9-1 Takakura-cho, Hachioji, Tokyo 192-8510, Japan; \\ masahiko_takino@agilent.com \\ 3 Laboratory of Theriogenology, Department of Veterinary Medicine, Azabu University, 1-17-71 Fuchinobe, \\ Chuo-ku, Sagamihara-shi, Kanagawa 252-5201, Japan; m-noguchi@azabu-u.ac.jp \\ * Correspondence: y-konishi@azabu-u.ac.jp; Tel.: +81-42-754-7111
}

Received: 3 June 2019; Accepted: 15 June 2019; Published: 20 June 2019

\begin{abstract}
Citreoviridin (CTVD), a mycotoxin called yellow rice toxin, is reported to be related to acute cardiac beriberi; however, its toxicokinetics remain unclear. The present study elucidated the toxicokinetics through in vivo experiments in swine and predicted the human toxicokinetics by comparing the findings to those from in vitro experiments. In vivo experiments revealed the high bioavailability of CTVD (116.4\%) in swine. An intestinal permeability study using Caco-2 cells to estimate the toxicokinetics in humans showed that CTVD has a high permeability coefficient. When CTVD was incubated with hepatic S9 fraction from swine and humans, hydroxylation and methylation, desaturation, and dihydroxylation derivatives were produced as the predominant metabolites. The levels of these products produced using human S9 were higher than those obtained swine S9, while CTVD glucuronide was produced slowly in human S9 in comparison to swine S9. Furthermore, the elimination of CTVD by human S9 was significantly more rapid in comparison to that by swine S9. These results suggest that CTVD is easily absorbed in swine and that it remains in the body where it is slowly metabolized. In contrast, the absorption of CTVD in humans would be the same as that in swine, although its elimination would be faster.
\end{abstract}

Keywords: citreoviridin; toxicokinetics; bioavailability; swine; Caco-2; S9

Key Contribution: CTVD bioavailability was high in swine in vivo; and was predicted to be high in humans based on an in vitro Caco-2 permeability study. Human S9 metabolized CTVD to hydroxylation, methylation, desaturation, and dihydroxylation metabolites and the activity was higher in comparison to swine. The glucuronidation activity of swine S9 was higher than that of human S9. The elimination of CTVD obtained by human S9 was faster than that by swine S9 in vitro.

\section{Introduction}

Citreoviridin (CTVD) (Figure 1) is a mycotoxin produced as a secondary metabolite of Penicillium citreonigrum, Aspergillus terreus, and Eupenicillium ochrosalmoneum [1]. CTVD has previously been detected in food including rice in various areas [2-6]. Contamination with CTVD, well-known as yellow rice toxin, often occurs due to inappropriate management after harvest [7]. The toxicity of CTVD is mainly accompanied by ascending paralysis, central nervous system disturbance and respiratory arrest, and fatal adverse effects may occur [8]. Because CTVD is mainly found as a contaminant in rice, 
these properties of CTVD can be a serious problem in countries in which people consume rice as a staple food such as Thailand, Brazil, and Japan.

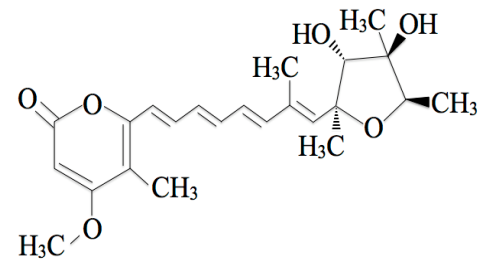

Figure 1. The chemical structure of citreoviridin (CTVD).

In a 2006 outbreak of beriberi in Brazil, 1207 people were diagnosed with beriberi, and 40 patients died [9]. Since P. citreonigrum and CTVD were detected in rice samples, CTVD was the suspected cause of the beriberi outbreak in that area [10].

Regarding the relationship between CTVD and beriberi, Uraguchi et al. reported, based on the results of an epidemiological investigation, the possibility of acute cardiac beriberi, which induces neurological symptoms and heart failure [11]. Ueno et al. reported that CTVD produced neurological symptoms similar to acute cardiac beriberi in humans based on experiments in mice and rats [12]. This disease has been caused by the consumption of moldy rice in areas in which rice preservation was inadequate. Studies on CTVD toxicity were performed using animal experiments from the 1940s to 1980s. These studies revealed that CTVD causes fatal adverse effects, with symptoms by ascending paralysis, disturbance of the central nervous system, and respiratory arrest [8]. The lethal dose 50\% (LD50) of CTVD in mice was reported to be $3.6-11.8 \mathrm{mg} / \mathrm{kg}$ subcutaneously and $7.5 \mathrm{mg} / \mathrm{kg}$ intraperitoneally $[13,14]$. When crude extract from yellow rice was administered to several mammals subcutaneously, intraperitoneally, and per os, the abovementioned typical neurological symptoms were observed [15]. In addition, the development of these symptoms in rats occurred earlier when the dose was increased [16]. Chronic exposure to CTVD has also been reported as a possible trigger of Keshan disease (an endemic disease in which patients present cardiomyopathy) [17]. Sakai et al. focused on the chronic toxicity at low doses, and reported that rats died when 1/300 of the oral LD $\mathrm{L}_{50}$ dose was administered subcutaneously every day for a six-month period [16]. This suggested that CTVD might accumulate in the body and have cumulative effects. Furthermore, the distribution of CTVD in the liver, kidney, heart, and brain, as determined by a photometric analysis, showed that CTVD remained in the liver, kidney, and heart of rats even at $52 \mathrm{~h}$ after its subcutaneous administration (SC) [12]. Although these results show the possibility that CTVD may easily remain in the body, the kinetics parameters, including oral bioavailability, have rarely been described.

The present study considered the cumulative properties of CTVD by elucidating the toxicokinetics and bioavailability of CTVD in vivo. Moreover, to estimate the bioavailability of CTVD in humans, the metabolic efficiency of CTVD in vitro was compared by an S9 metabolic study, and a permeability study was conducted using Caco-2 cells as a human intestinal cell model. First, the kinetics of CTVD in plasma were investigated by administering CTVD intravenously and orally to swine in an in vivo study. Subsequently, the intestinal permeability of CTVD was evaluated using Caco-2 cells and the metabolism of CTVD and the production of its main metabolites were investigated using S9 fractions obtained from swine and humans. The parameters thus obtained may contribute to improving the knowledge on the risk of CTVD.

\section{Results}

\subsection{The Toxicokinetics of CTVD in Swine}

None of the swine that received CTVD intravenously or orally showed adverse clinical signs. The plasma CTVD concentration profile after intravenous administration (IV) is shown in Figure 2a. The rate constant $(\mathrm{Kel})$ was small $\left(0.5 \pm 0.1 \times 10^{-1} \mathrm{~h}^{-1}\right)($ Table 1$)$. The mean half-life of CTVD was 
$16.2 \pm 4.3 \mathrm{~h}$, which was relatively long. The volume of distribution (Vd) was greater than the total body water $(1.5 \pm 0.2 \mathrm{~L}$ ), and the mean residence time (MRT) of CTVD was estimated to be $14.6 \pm 1.2 \mathrm{~h}$. To calculate the bioavailability of CTVD based on the different estimated parameters, the area under the curve (AUC) was determined to be $1512.9 \pm 331.7 \mathrm{~h} \cdot \mathrm{ng} / \mathrm{mL}$, with extrapolation to infinity.
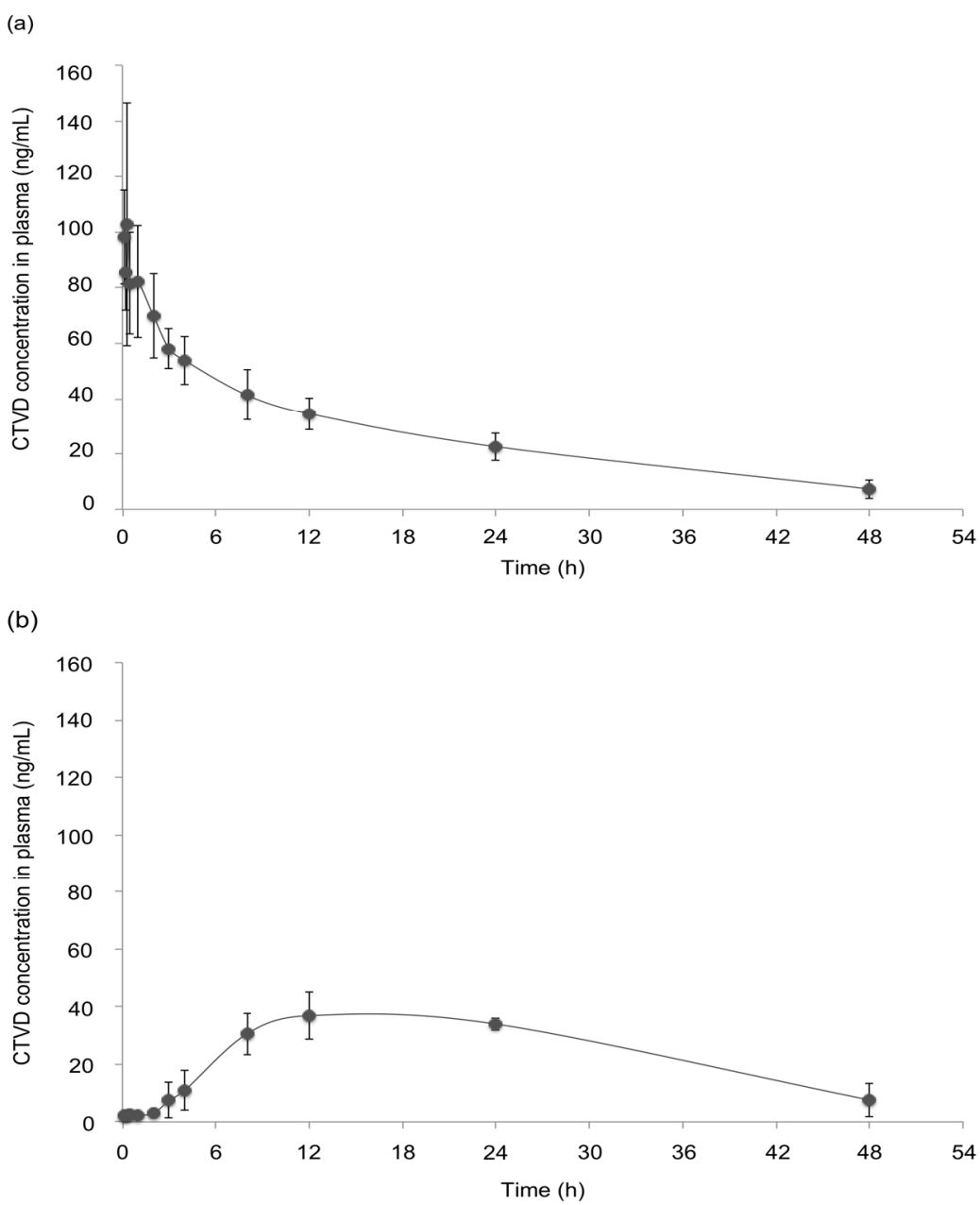

Figure 2. The CTVD concentration-time profiles in the plasma of swine after IV and oral administration (PO). CTVD (0.1 mg/kg.BW) was administered intravenously (a) and orally (b). Control plasma was obtained on the day before administration. Values are presented as the mean \pm standard deviation (SD). $n=4$ in both groups.

Table 1. The toxicokinetic parameters in swine that received CTVD intravenously and orally.

\begin{tabular}{|c|c|c|c|c|c|c|c|c|c|c|c|}
\hline & BW (kg) & $\begin{array}{c}\text { Kel } \\
\times 10^{-1} \\
\left(h^{-1}\right)\end{array}$ & $\mathrm{T}_{1 / 2}$ (h) & $\begin{array}{c}\text { Vd or } \\
\text { Vd/F } \\
\text { (L) }\end{array}$ & MRT (h) & $\begin{array}{c}\mathrm{AUC}_{\mathrm{t}} \\
(\mathrm{h} \cdot \mathrm{ng} / \mathrm{mL})\end{array}$ & $\begin{array}{c}\mathrm{AUC} \infty \\
\text { (h.ng/mL) }\end{array}$ & $\underset{(\mathrm{ng} / \mathrm{mL})}{\mathrm{C}_{\max }}$ & $\mathrm{T}_{\max }(\mathrm{h})$ & $F_{t}(\%)$ & F (\%) \\
\hline IV & $9.4 \pm 1.3$ & $0.5 \pm 0.1$ & $16.2 \pm 4.3$ & $1.5 \pm 0.2$ & $14.6 \pm 1.2$ & $1322.2 \pm 224.4$ & $1512.9 \pm 331.7$ & - & - & - & - \\
\hline
\end{tabular}

BW, body weight; $\mathrm{C}_{\max }$, maximum plasma CTVD level; $\mathrm{T}_{\max }$, time of maximum plasma CTVD concentration; Kel, the rate constants; $\mathrm{T}_{1 / 2}$, biological half-life of the elimination; $\mathrm{Vd}$ or $\mathrm{Vd} / \mathrm{F}$, apparent volume of distribution in IV or $\mathrm{PO}$; MRT, mean residence time; AUCt, area under the curve from the curve 0 to the last quantifiable concentration; AUC $\infty$, area under the curve from the curve 0 to infinity; $F_{t}$, bioavailability calculated using mean AUC $C_{t}$ after PO and IV; F, bioavailability calculated using mean AUC $\infty$ after PO and IV. With the exception of $F_{t}$ and F, all values are presented as the mean \pm SD.

The CTVD concentration profile in plasma after PO administration is shown in Figure $2 b$. The peak plasma concentration $\left(\mathrm{C}_{\max }, 38.2 \pm 6.7 \mathrm{ng} / \mathrm{mL}\right)$ was observed at $15.0 \pm 6.0 \mathrm{~h}\left(\mathrm{~T}_{\max }\right)$ after PO (Table 1$)$. The Kel was $0.4 \pm 0.2 \times 10^{-1} \mathrm{~h}^{-1}$, which was low and similar to the value after IV administration. 
The $\mathrm{T}_{1 / 2}$ was approximately one day $(21.4 \pm 12.7 \mathrm{~h})$, and the $\mathrm{Vd} / \mathrm{F}$ was relatively large $(1.7 \pm 0.3 \mathrm{~L})$. The MRT obtained from those values was relatively long $(19.6 \pm 4.0 \mathrm{~h})$ (Table 1), suggesting that CTVD persisted in the bodies of swine. The AUC extrapolated to infinity was $1761.1 \pm 813.5 \mathrm{~h} \cdot \mathrm{ng} / \mathrm{mL}$. The estimated bioavailabilities in swine from $\mathrm{AUC}_{t}$ and $\mathrm{AUC} \infty$ was $79.3 \%$ and $116.4 \%$, respectively.

\subsection{Permeability Study Using Caco-2 Cells}

The results of the administration study showed that CTVD had high bioavailability in swine. In order to compare the intestinal permeability of CTVD in humans with the bioavailability of CTVD in swine, the permeability was investigated using Caco-2 cells. The Caco- 2 cell model is an in vitro model used to evaluate intestinal permeability and the influence of chemical compounds on the intestinal barrier function in humans.

The apparent permeability coefficient (Papp) estimated from a Caco-2 permeability assay has been reported to be well correlated with the human in vivo absorption data for many agents [18,19]. The transepithelial electrical resistance (TEER) value is generally accepted to reflect the integrity of the tight junction dynamics in Caco-2 cells [20]; thus, the TEER was measured at 1 and $2 \mathrm{~h}$ after exposure to 3 and $10 \mu \mathrm{mol} / \mathrm{L}$ of CTVD. Our results showed no marked change in the TEER over time at any concentration (data not shown). The rate of CTVD transport from the apical (AP) side to the basolateral (BL) side was calculated based on the concentration of CTVD in the BL compartment. The Papp was calculated as described in a previous paper [21]. The Papp after $2 \mathrm{~h}$ of incubation with 3 and $10 \mu \mathrm{mol} / \mathrm{L}$ CTVD was $52.2 \times 10^{-6}$ and $42.6 \times 10^{-6}(\mathrm{~cm} / \mathrm{s})$, respectively, in the AP-BL direction (Table 2). These findings indicated that human intestinal cells were highly permeable to CTVD in vitro.

Table 2. The Papp at each concentration of CTVD.

\begin{tabular}{|c|c|c|}
\hline Parameter & $3 \mu \mathrm{mol} / \mathrm{L}$ & $10 \mu \mathrm{mol} / \mathrm{L}$ \\
\hline $\operatorname{Papp}\left(\times 10^{-6} \mathrm{~cm} / \mathrm{s}\right)$ & $52.2 \pm 28.3$ & $42.6 \pm 17.7$ \\
\hline
\end{tabular}

Papp, apparent permeability coefficient of Caco-2 cells treated with 3 and $10 \mu \mathrm{mol} / \mathrm{L}$ CTVD in an AP chamber for $2 \mathrm{~h}$. Values are presented as the mean $\pm \mathrm{SD}$.

\subsection{CTVD Elimination and the CTVD Metabolite Profile Following Incubation with S9 Fraction In Vitro}

The fact that it took more than $40 \mathrm{~h}$ to eliminate CTVD in plasma after IV or PO administration in swine in vivo experiments suggested that CTVD was poorly metabolized in the liver. Thus, to confirm the metabolic activity of CTVD and the metabolites of CTVD produced in the liver, the residual CTVD concentration was measured after incubation in vitro with hepatic S9 fraction from swine, and the profile of the CTVD metabolites produced was determined using Q-TOF. These data obtained from the swine S9 fraction were subsequently compared to those obtained using human S9 fraction.

The elimination of CTVD as well as the metabolites produced when CTVD was incubated with S9 fraction supplemented with NADP was investigated. NADP is a coenzyme of dehydrogenase that is often used in metabolism assays with S9 [22,23]. Incubation was conducted according to the method of $\mathrm{Wu}$ et al. [24]. As a result, hydroxylation and methylation, desaturation, and dihydroxylation derivatives were detected as the main metabolites of CTVD. The extracted ion chromatogram (EIC) and accurate mass spectra of these metabolites are shown in Figure A1 (Appendix A). These detected metabolites were confirmed from monoisotopic mass and mass accuracy (Table A1). Although the concentration of CTVD incubated with human hepatic S9 fraction decreased as the duration of incubation increased, the concentration of CTVD incubated with swine hepatic S9 fraction was almost unchanged from $30 \mathrm{~min}$ of incubation to $240 \mathrm{~min}$ of incubation (Figure 3a). Furthermore, the concentration of CTVD after 240 min of incubation with human hepatic S9 fraction was significantly lower than that after incubation with swine hepatic S9. 

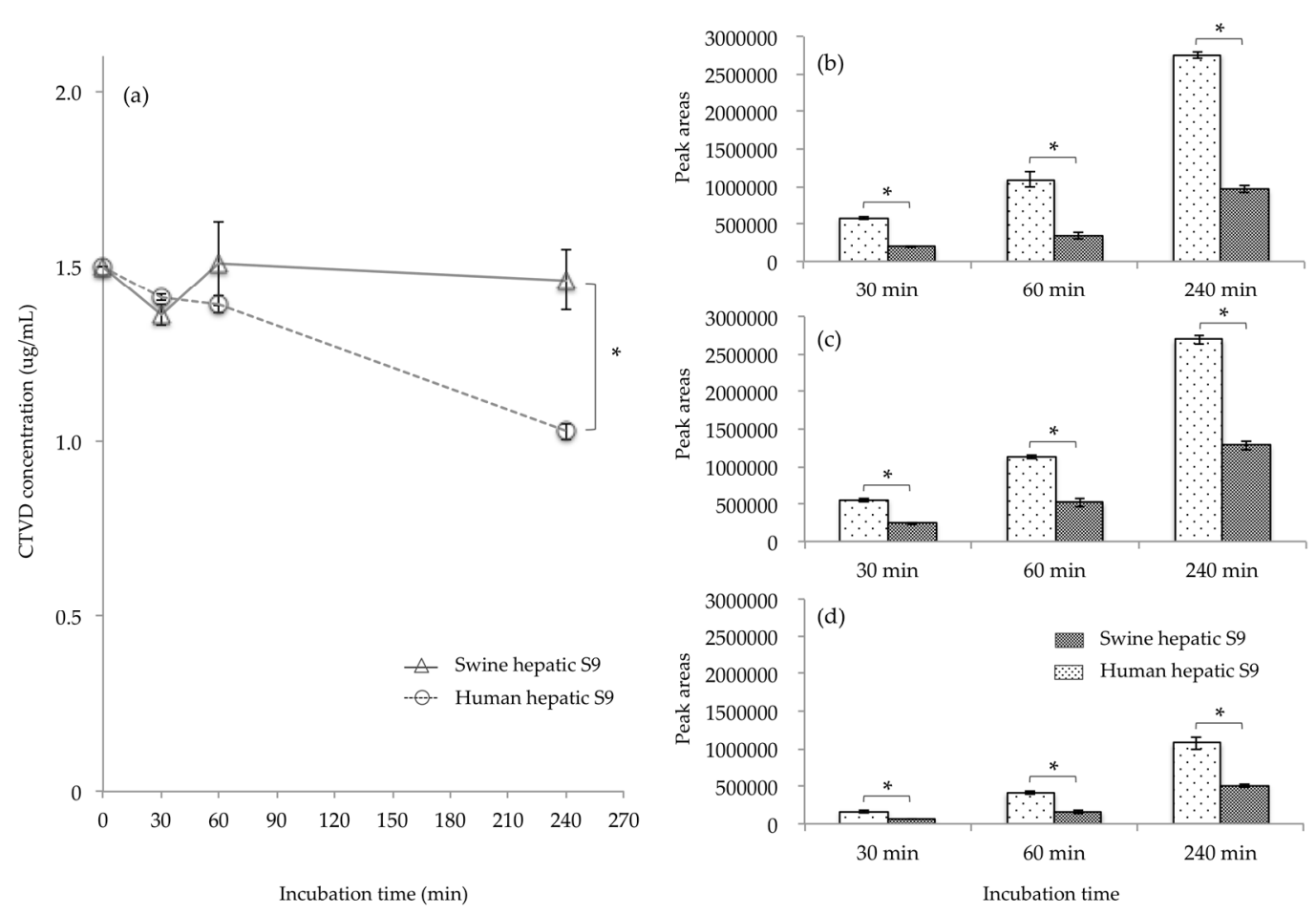

Figure 3. The comparison of the CTVD concentration and the main metabolites in humans and swine, obtained by incubating of CTVD with hepatic S9 fractions of humans and swine. CTVD $(1.5 \mu \mathrm{g} / \mathrm{mL})$ was incubated with the hepatic S9 fractions of humans and swine supplemented with NADP as a coenzyme. The CTVD concentrations at 30,60, and $240 \mathrm{~min}$ after the start of incubation are described (a). The main metabolites produced in humans and swine are shown in (b-d). The metabolites in humans and swine at each time-point were compared based on the mean peak area of each metabolite. (b-d) show the mean peak areas of hydroxylation and methylation, desaturation, and dihydroxylation derivatives, respectively, following incubation with human or swine hepatic S9, respectively. Values are presented as the mean \pm SD. Asterisks indicate a statistically significant difference $(p<0.05)$.

Since the hydroxide of CTVD did not show a quantitative change over time from the metabolic reaction of S9, products other than those derived from the control group due to the metabolic reaction with S9 were considered to be metabolites of CTVD. The main metabolite forms of CTVD were found to have been produced by hydroxylation and methylation, desaturation, and dihydroxylation. The main metabolites could not be quantified because standard substances of the metabolites detected were not commercially available. Thus, the metabolites in humans and swine at each time-point were compared based on the mean area of each metabolite. The metabolite peak area after incubation with human hepatic S9 fraction was two to three times higher than that after incubation with the swine hepatic S9 fraction for all metabolites (Figure $3 b-d$ ). These results indicate that human hepatic $S 9$ fraction has a greater ability to metabolize CTVD than swine hepatic $S 9$ fraction.

\subsection{CTVD Elimination and the CTVD Glucuronide Profile Following Incubation with S9 In Vitro}

Glucuronide is a well-known metabolite produced from the detoxification of mycotoxins. However, after incubation with S9 fraction and NADP as a coenzyme, no glucuronide was recognized in our swine or human metabolite models. Moreover, it is reported that swine have low sulfate conjugation ability; this has been reported to be alternated by processes such as glucuronidation [25]. For this reason, the glucuronidation of CTVD in the presence of uridine-5' -diphosphoglucuronic acid trisodium salt (UDPGA) was examined in order to compare the detoxification ability between swine and humans. UDPGA is a cosubstrate used in the glucuronidation reaction [26]. Swine and human hepatic S9 were used for incubation, and CTVD glucuronide was observed at 30, 60, and $240 \mathrm{~min}$ after incubation. The EIC and accurate mass spectrum of CTVD glucuronide are shown in Figure A2. Of note, with 
swine hepatic S9, CTVD glucuronide was detected at $60 \mathrm{~min}$ and the amount increased over time until 240 min, while CTVD glucuronide was not detected at 30, 60, or $240 \mathrm{~min}$ with human hepatic S9 (Figure 4).

Because the standard substance of CTVD glucuronide was not commercially available, the same method that was used for the comparison of S9 fractions supplemented with NADP was applied. The mean area of CTVD glucuronide after incubation with swine hepatic S9 fraction for 240 min was approximately twice that after incubation with human hepatic S9 fraction for $240 \mathrm{~min}$ (Figure 4).

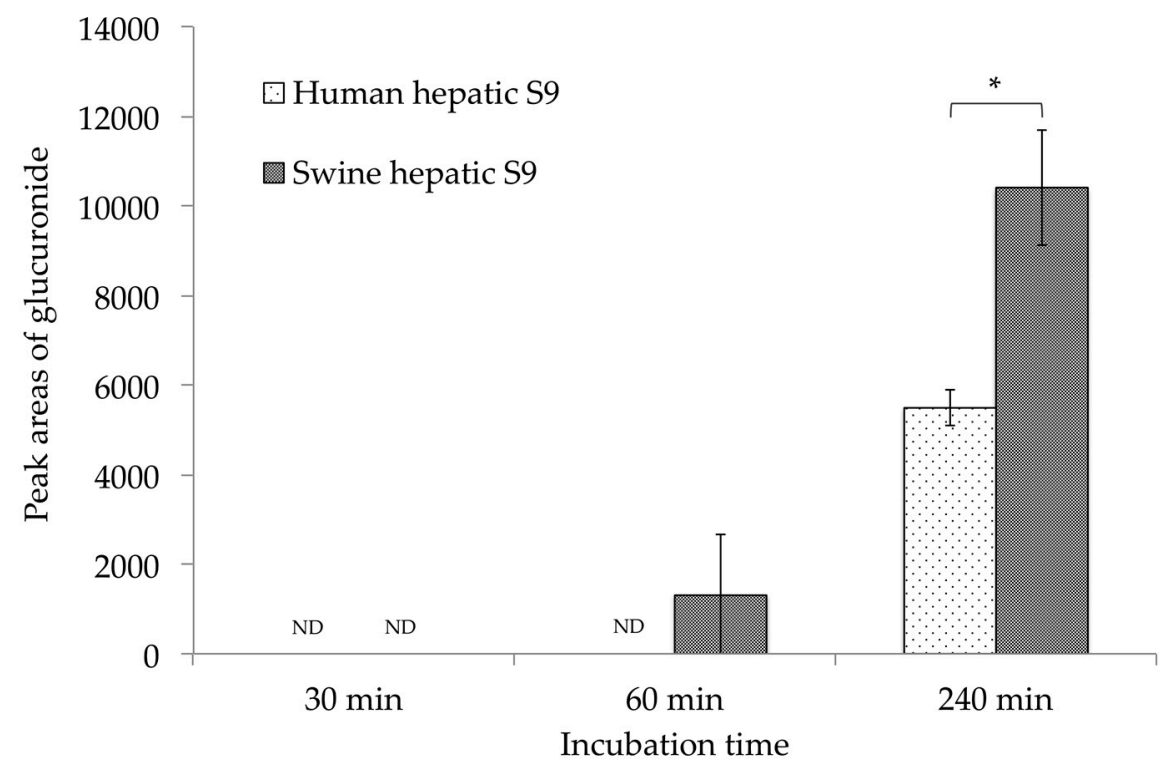

Figure 4. A comparison of the CTVD glucuronidation during incubation with human and swine S9 fractions supplemented with UDPGA. CTVD $(1.5 \mu \mathrm{g} / \mathrm{mL})$ was incubated with human and swine hepatic S9 fractions supplemented with UDPGA as a coenzyme. The amount of CTVD glucuronide at 30, 60, and 240 min was measured by Q-TOF. The metabolites in humans and swine at each time-point were compared based on the mean area of each metabolite. Values are presented as the mean $\pm \mathrm{SD}$. Asterisks indicate a statistically significant difference $(p<0.05)$. ND, not detected.

\section{Discussion}

Swine are known to share some physiological and anatomic similarities with humans, including food habits. The toxicokinetics of CTVD were therefore investigated in swine for extrapolation to humans. The bioavailability of mycotoxins has been reported for several major compounds. Deoxynivalenol (48-109.8\% in swine) [27-29] and ochratoxin A (65.7\% in swine) [30] have relatively high bioavailability, and the bioavailability of zearalenone in swine is reported to be $80-85 \%$ [31]. The result of the present study was over $100 \%$ by calculated from AUC $\infty$. This was possible to have been overestimated, because the extrapolation estimate (from $48 \mathrm{~h}$ to infinity) in $\mathrm{PO}$ administration had $68 \%$ of $\mathrm{AUC}_{\mathrm{t}}$. However, the bioavailability estimated from $\mathrm{AUC}_{\mathrm{t}}$ (from 0 to $48 \mathrm{~h}$ ) was $79.3 \%$, then it was suggested that CTVD was also a mycotoxin with similarly high bioavailability to these compounds (Table 1). Generally, lipophilic substances appear to be easily absorbed by the intestine through passive transport. Aflatoxin and zearalenone are lipophilic and low-molecular mass molecules that are said to be transported through passive diffusion [32]. CTVD is a similarly lipophilic and low-molecular mycotoxin with a low-molecular mass; thus, it is considered to be absorbed by passive transport. Lipophilic compounds access the systemic circulation through the intestinal lymphatic system by which these compounds avoid the first pass effect [33]. Thus, these properties of CTVD may be one reason for its high bioavailability.

In the permeability experiment using Caco-2 cells, CTVD showed a high Papp (Table 2) despite having no marked effect on the TEER. The Papp of CTVD was similar to that of propranolol as a model 
of lipophilic drug [34]. Furthermore, the Papp was higher than the Papp values of deoxynivalenol $\left(0.19 \pm 0.02\left[\times 10^{-6} \mathrm{~cm} / \mathrm{min}\right]\right)[35]$ and zearalenone $\left(10.4 \pm 4.7\left[\times 10^{-6} \mathrm{~cm} / \mathrm{s}\right]\right)[36]$, although it was lower than that of aflatoxin M1 $\left(105.10 \pm 7.98\left[\times 10^{-6} \mathrm{~cm} / \mathrm{s}\right]\right)[37]$. The permeability coefficient from the Caco-2 cell assay has been shown to be correlated with the bioavailability and intestinal absorbency, following a sigmoidal curve (wherein a substance with a high permeability coefficient has high absorbency) $[18,19]$. Considering that the results of our in vivo study using swine indicated the relatively higher bioavailability of CTVD, the result of the Caco-2 study suggested that the bioavailability of CTVD in humans would be similarly high to that in swine.

The plasma CTVD concentration showed almost no increase until $3 \mathrm{~h}$ after PO to swine (Figure $2 b$ ). The dwell time of digesta in the stomach of swine has been reported to range from one to three hours [38]. As CTVD was administered with feed in this study, CTVD may have been retained with digesta in the stomach. Some mycotoxins have been reported to be absorbed from the stomach [39,40]. However, in the present study, a marked increase in the plasma CTVD concentration was noted from three hours after its administration; thus, CTVD may be poorly absorbed from the stomach.

In the in vivo study, the elimination of CTVD from the body of swine appeared to be quite slow, the Vd of CTVD in swine was greater than $1 \mathrm{~L}$ (Table 1). Generally, drugs with a Vd exceeding $1 \mathrm{~L}$ are considered to be widely distributed to the body tissue [41]. Ueno et al. [12] performed an in vivo study on the distribution and elimination of CTVD, which supported our results. In their study [12], they noted that after the SC of extracted CTVD, CTVD was rapidly distributed from the site of administration to the main organs, including the liver, kidney, and heart. They also found that the concentration of CTVD was highest in the liver after $8 \mathrm{~h}$, and that $<1 \%$ of the total administered dose could still be detected in the liver, even after $52 \mathrm{~h}$. Thus, from the results of the present study, CTVD was suggested to be widely distributed to the body tissue. Regarding other mycotoxins, ochratoxin A (84.5 h in swine, $840 \mathrm{~h}$ in monkey) [29,42] and aflatoxin B1 (91.8 h in rat) [43] are reported to have long elimination half-lives. In contrast, the elimination half-lives of fumonisin B1 (182 min in swine) and deoxynivalenol (7.2-15.2 $\mathrm{h}$ in swine) are reported to be short [44]. In this respect, CTVD is a mycotoxin with a relatively long half-life (Table 1). Hou et al. proposed that CTVD bound plasma albumin [45]. Ochratoxin A is generally accepted to bind plasma albumin [46,47], which may explain why CTVD showed a long elimination half-life. In addition, Sakai et al. reported that extract from yellow rice had a lethal effect, even when exposed rats were given daily doses of $1 / 300$ of $L_{50} P O$ for 16 months [16]. In the present study, the toxicokinetics of CTVD in swine showed that CTVD had high bioavailability and persisted in the body for a relatively long period of time. This suggested that CTVD might accumulate in the body with chronic exposure, and this result was considered to reflect the above report describing the adverse effects of chronic exposure.

To estimate the bioavailability in humans, the metabolites in human hepatic S9 fraction were examined and compared to those produced by swine S9 fraction in an in vitro experiment. Regarding the metabolites present in the S9 fraction of humans, the main metabolites-including hydroxylation and methylation, desaturation, and dihydroxylation derivatives-were the same as those in the swine S9 fraction (Figure 3). Marked differences were noted in the metabolite-producing ability of the hepatic S9 fraction; the metabolization when human S9 fraction was used was higher than that when swine S9 fraction was used. Although glucuronide was detected among the metabolites produced by the hepatic S9 fractions of both species when supplemented with UDPGA, the glucuronidation of CTVD in humans was shown to be slower in comparison to in swine (Figure 4). Interspecies differences in the hepatic glucuronidation of deoxynivalenol have been reported [48]. Moreover, swine have no sulfate conjugation ability (or lower ability in comparison to other species); thus, it has been shown that sulfatic conjugation in swine occurs via pathways other than phase II pathways [25]. Furthermore, in the metabolism of CTVD, glucuronidation might compensate for sulfatic conjugation in swine due to their low sulfate conjugation ability, and this was considered to be a factor that caused the increased production of glucuronide from CTVD in pigs in comparison to humans. On the other hand, because CTVD was more metabolized in humans than in pigs, it was suggested that in humans, CTVD may 
be metabolized by phase II pathways other than glucuronidation. Further investigations should be performed to test this hypothesis. Overall, the results of our in vitro study using S9 fraction suggested that the metabolism of CTVD in the human liver would be faster than that in the swine liver (Figure 3).

One limitation associated with the present study is that frequent blood drawing within the first hour after administration was performed under anesthesia, due to considerations for the animals' welfare, and that the effect in relation to absorption and metabolism was unclear. However, the results of the present study are important in that the toxicokinetic parameters in the in vivo and in vitro experiments clearly demonstrated that CTVD can easily remain in the body. This is in line with the results from previous animal experiments. In the future, although it will be necessary to accumulate further data, this research may provide useful information for evaluating the risk associated with the administration of CTVD.

Although previous animal experiments demonstrated that CTVD remains in the body for a long time, in this study we performed metric analyses to reveal the toxicokinetics for the first time. The results indicated that CTVD has high bioavailability in swine and that it persisted in the body for a relatively long time. Thus, CTVD may bring about adverse effects due to accumulation as a result of chronic exposure. In addition, the comparison of the in vitro findings in humans and swine suggested that the bioavailability of CTVD in humans was similarly high to that in swine, although CTVD appears to be metabolized more quickly in humans than in swine.

\section{Materials and Methods}

\subsection{Reagents}

CTVD (Figure 1) (purity: 88.8\%) was extracted from P. citreonigrum isolated by Shiratori et al. [6] with reference to the method of da Rocha et al. [49]. Regarding the approximately $12 \%$ impurities, most were hydroxides of CTVD. These hydroxides did not change quantitatively during the reaction of S9 (data not shown). The Caco-2 cell lines were provided by the Division of Pharmacognosy, Phytochemistry, and Narcotics of the National Institute of Health Sciences (Kanagawa, Japan). Human and swine hepatic S9 fractions were purchased from Sekisui XenoTech, LLC. (Kansas City, KS, USA). NADP, Glucose-6-Phosphate, Hank's balanced salt solution (HBSS) and HEPES were purchased from Sigma-Aldrich (St. Louis, MO, USA). UDPGA was obtained from Nacalai Tesque, Inc. (Kyoto, Japan). Alamethicin was obtained from LKT Laboratories, Inc. (St. Paul, MN, USA). Inactivated fetal bovine serum was obtained from Biowest (Nuaillé, France). Dulbecco's modified Eagle's medium (DMEM), penicillin, and streptomycin were purchased from Invitrogen Japan (Tokyo, Japan). Nonessential amino acids were obtained from MP Bio Science (Derbyshire, UK). The Corning ${ }^{\mathrm{TM}}$ BioCoat $^{\mathrm{TM}}$ Intestinal Epithelium Differentiation Environment Kit was purchased from Corning (NY, USA). Medetomidine hydrochloride and butorphanol tartrate were obtained from Meiji Seika Pharma Co., Ltd. (Tokyo, Japan). Midazolam was obtained from Astellas Pharma Inc. (Tokyo, Japan). Other reagents were purchased from Fujifilm Wako Pure Chemical Corporation (Osaka, Japan).

\subsection{Administration Study}

\subsubsection{Animals and Diets}

Swine (barrows; Landrace $\times$ Large White $\times$ Duroc) were obtained from CIMCO Co., Ltd. (Tokyo, Japan). They were housed in individual cages ( $0.88 \mathrm{~m}$ wide, $1.3 \mathrm{~m}$ deep), with ad libitum access to water, and were fed a commercial formula feed in quantities of $1.5-2 \%$ of their body weight (BW) daily. All protocols were approved by the Animal experiment ethics committee of Azabu University (Approval number: 170829-1). 


\subsubsection{Administration and Blood Sampling}

CTVD stock solution was prepared by dissolving CTVD in acetonitrile to a concentration of $10 \mathrm{mg} / \mathrm{mL}$. The required amount of CTVD was moved from the stock solution into a tube and dried with nitrogen. The dried CTVD was then redissolved in ethanol-saline (ratio, 1:4) and was used as a test solution. Following three days of acclimatization, administration studies were carried out. CTVD $(0.1 \mathrm{mg} / \mathrm{kg} \cdot \mathrm{BW})$ was intravenously administered to swine $(n=4)$ via the auricular vein. For PO administration $(n=4), 10 \mathrm{mg} / \mathrm{mL}$ of CTVD-ethanol solution and a small amount of water were added to feed $(10 \mathrm{~g})$, for a dose of $0.1 \mathrm{mg} / \mathrm{kg}$.BW. This was then fashioned into a sphere and fed to the animals at the time of feeding. It was visually confirmed that the animals had eaten the CTVD-contaminated feed.

Blood was sampled from the jugular vein at $0 \mathrm{~min}$ (before administration), and 5, 10, 20, and $30 \mathrm{~min}$ and 1, 2, 3, 4, 8, 24, and $48 \mathrm{~h}$ after administration. Blood samples were placed into heparinized tubes and stored on ice until centrifugation. After centrifugation $(1919 \times \mathrm{g}, 10 \mathrm{~min})$, the plasma was temporarily stored at $-80{ }^{\circ} \mathrm{C}$. Plasma samples were prepared according to the method of Devreese et al. [50]. A three-fold volume of acetonitrile was mixed with the plasma samples, which were then centrifuged again $\left(8500 \times g, 4^{\circ} \mathrm{C} 10 \mathrm{~min}\right)$ after mixing with a vortex mixer for $15 \mathrm{~s}$. The supernatants were transferred into amber screw-top vials and dried under nitrogen gas. The samples were stored at $-30{ }^{\circ} \mathrm{C}$ until the analysis.

In order to frequently sample blood via a cervical part of swine in a short period of time (up to $1 \mathrm{~h}$ after administration), taking animal welfare into account, CTVD was administered intravenously and orally, followed by the immediate administration of $0.1 \mathrm{mg} / \mathrm{kg}$ of mixed anesthetics (medetomidine hydrochloride:midazolam:butorphanol tartrate $=3: 2: 2$ ) via intramuscular injection. Therefore, blood samplings from $5 \mathrm{~min}$ to $1 \mathrm{~h}$ after CTDV administration were conducted under anesthesia. Each animal was awake at approximately $1 \mathrm{~h}$ after anesthetization, blood samplings from 2 to $48 \mathrm{~h}$ after CTDV administration were conducted under awakening.

\subsubsection{Toxicokinetic Analyses}

The toxoicokinetics were analyzed using the Phoenix WinNonlin 6.4 software program (Certara, St. Louis, MO, USA). The bioavailability was determined using the following equation by calculating the AUC of the IV and PO data, which were determined with extrapolation to infinity.

$$
\mathrm{F}=\frac{A_{U C} C_{P O} / \text { Dose }_{P O}}{A U C_{I V} / \text { Dose }_{I V}} \times 100
$$

where $\mathrm{F}$ is the bioavailability of CTVD. AUC ${ }_{P O}$ or ${ }_{I V}$ represents the mean area under the curve after PO or IV administration. Dose $P O$ or $I V$ represent the actual dose by PO or IV administration.

\subsection{Permeability Study Using Caco-2 Cells}

Cell culture and a permeability study were carried out by the method of Kadota et al. [21]. CTVD solutions ( 3 and $10 \mathrm{mmol} / \mathrm{mL}$ ) were prepared by dissolving dried CTVD in DMSO. The permeability study was carried out using a Corning ${ }^{\mathrm{TM}}$ BioCoat ${ }^{\mathrm{TM}}$ Intestinal Epithelium Differentiation Environment Kit (Corning, NY, USA). Cell incubation and induction of differentiation were performed in accordance with the protocol of the kit. CTVD solutions were added to Enterocyte Differentiation Medium (EDM) containing $0.08 \%$ MITO + serum extender, with CTVD at concentrations of 3 and $10 \mu \mathrm{mol} / \mathrm{L}$.

EDM containing CTVD was exposed to Caco-2 cells from the apical (AP) side. The TEER of the $\mathrm{AP}$ and BL sides was measured at 0 (before exposure), 1 and $2 \mathrm{~h}$ (after exposure) using a Millicell ERS device (Millipore, Molsheim, France). To determine the CTVD concentration at the AP and BL sides, transport buffer was collected from both sides. After transferring $400 \mu \mathrm{L}$ of collected buffer (per side) to a microtube, a three-fold volume of acetonitrile was added. Samples were mixed with a vortex mixed, followed by centrifugation at $8500 \times \mathrm{g}$ for $10 \mathrm{~min}$ at $4{ }^{\circ} \mathrm{C}$. The supernatant was then transferred 
to an amber vial and dried with nitrogen gas. Samples were stored at $-30{ }^{\circ} \mathrm{C}$ until an analysis by liquid chromatography tandem mass spectrometry (LC-MS/MS).

\subsection{Production of CTVD Metabolites by Incubating with S9 Fractions}

The incubation of S9 supplemented with NADP was carried out with reference to a previous report [24]. CTVD stock solution $(25 \mu \mathrm{L})$ was transferred into a microtube and dried with nitrogen. CTVD solution $(250 \mu \mathrm{g} / \mathrm{mL})$ was prepared by redissolving dried CTVD with $1 \mathrm{~mL}$ of DMSO. CTVD additive solution $(150 \mu \mathrm{g} / \mathrm{mL})$ was prepared by mixing $600 \mu \mathrm{L}$ of CTVD solution $(250 \mu \mathrm{g} / \mathrm{mL})$ and $400 \mu \mathrm{L}$ of a base buffer. The total volume of the test solution was $500 \mu \mathrm{L}$. The final concentrations of each factor in the test solution were as follows: $\mathrm{MgCl}_{2}(5 \mathrm{mmol} / \mathrm{L})$, Glucose-6-phosphate $(5 \mathrm{mmol} / \mathrm{L})$ and NADP $(0.5 \mathrm{mmol} / \mathrm{L})$. The concentrations of S9 and CTVD in the test solution were $0.5 \mathrm{mg} / \mathrm{mL}$ and $1.5 \mu \mathrm{g} / \mathrm{mL}$, respectively. After adding CTVD, the test solution was incubated in a warm bath at $37^{\circ} \mathrm{C}$ for 30,60 , or $240 \mathrm{~min}$. The reaction of the test solution was terminated by adding the same amount $(500 \mu \mathrm{L})$ of acetonitrile. Each sample was mixed in a vortex mixer at $30 \mathrm{~s}$, followed by centrifugation at $6000 \times \mathrm{g}$ for $10 \mathrm{~min}$ at $4{ }^{\circ} \mathrm{C}$. The supernatant was transferred to an amber vial and dried with nitrogen gas. Dried samples were stored at $-30^{\circ} \mathrm{C}$ until the analysis.

S9 was incubated with UDPGA as follows: first, a mixture ( $S 9$ (final concentration, $0.5 \mathrm{mg} / \mathrm{mL}$ ), Tris- $\mathrm{HCl}$ buffer ( $\mathrm{pH} 7.4$; final concentration, $50 \mathrm{mmol} / \mathrm{L}$ ), $\mathrm{MgCl}_{2}$ (final concentration, $0.5 \mathrm{mg} / \mathrm{mL}$ ), alamethicin (final concentration, $0.25 \mu \mathrm{g} / \mathrm{mL}$ ) and CTVD (final concentration, $1.5 \mu \mathrm{g} / \mathrm{mL}$ )) was pre-incubated at $37^{\circ} \mathrm{C}$ for $5 \mathrm{~min}$. The total volume was then brought to $1 \mathrm{~mL}$ by adding UDPGA (final concentration, $3 \mathrm{mmol} / \mathrm{L}$ ), and incubation was started at $37^{\circ} \mathrm{C}$. A $100 \mu \mathrm{L}$ aliquot of the sample was collected from each mixture at 30, 60, and $240 \mathrm{~min}$ from the start of incubation. An equal amount of acetonitrile was then added to terminate the reaction. After centrifugation at $9000 \times g$ for $5 \min$ at $4{ }^{\circ} \mathrm{C}$, the supernatant was dried with nitrogen gas. Samples were stored until use at $-30^{\circ} \mathrm{C}$.

\subsection{Quantification of CTVD and Detection of Metabolites}

Dried samples from the administration and permeability studies were redissolved in methanol for the analysis. The quantification of CTVD in samples was conducted under the following analytical conditions: LC was performed using an Agilent 1290 Infinity LC System (Agilent Technology Ltd., Santa Clara, CA, USA), and separation was performed using a ZORBAX Eclipse plus C18 (100 mm, $2.1 \mathrm{~mm}, 1.8 \mu \mathrm{m}$; Agilent Technology Ltd.). The mobile phases used were $5 \mathrm{mmol} / \mathrm{L}$ acetic ammonium and methanol, and the solvent composition was increased in a linear gradient from $50 \%$ organic modifier to $85 \%$ at $7 \mathrm{~min}$. The flow rate was $0.25 \mathrm{~mL} / \mathrm{min}$, the column oven temperature was $40{ }^{\circ} \mathrm{C}$, and the injection volume was kept at $2 \mu \mathrm{L}$ (administration study) or $0.1 \mu \mathrm{L}$ (permeability study). MS was performed using the Agilent 6470 Triple Quadrupole LC/MS system (Agilent Technology, Ltd.). The ion source was the Agilent Jet Stream (AJS) (Positive/Negative mode), and the drying gas temperature and flow rate were $250{ }^{\circ} \mathrm{C}$ and $10 \mathrm{~L} / \mathrm{min}$, respectively, while the sheath gas temperature and flow rate were $400{ }^{\circ} \mathrm{C}$ and $12 \mathrm{~L} / \mathrm{min}$, respectively. The fragmentor voltage was $140 \mathrm{~V}$, and the nozzle voltage was $1000 \mathrm{~V}$. MRM transition was performed at $m / z=403>139(30 \mathrm{eV}), 297(15 \mathrm{eV})$.

To detect metabolites by incubation using S9 supplemented with NADP, dried samples were re-dissolved in methanol. The LC system and analytical column were the same as described above. The mobile phases used were $0.1 \%$ formic acid and methanol, and the solvent composition was changed in a linear gradient from $10 \%$ methanol to $100 \%$ methanol in $30 \mathrm{~min}$. The flow rate was $0.2 \mathrm{~mL} / \mathrm{min}$. The quantification of CTVD and the search for metabolites of CTVD were performed using an Agilent 6545 quadrupole time-of-flight mass spectrometer (Q-TOF) LC/MS system (Agilent Technologies, Ltd.). The drying gas temperature and fragmentor voltage were $350{ }^{\circ} \mathrm{C}$ and $120 \mathrm{~V}$, respectively, and the other conditions were as described above. Screening for metabolites was based on a database of predicted metabolites (Table A2). Then, peaks from control were excepted.

To detect CTVD glucuronide by incubation of S9 with UDPGA, dried samples were redissolved in acetonitrile. MS was performed using the Agilent 6530 Q-TOF LC/MS system (Agilent Technology, 
Ltd.). The mobile phases used were $5 \mathrm{mmol} / \mathrm{L}$ acetic ammonium and methanol, and the solvent composition was increased in a linear gradient from $10 \%$ organic modifier to $100 \%$ at $30 \mathrm{~min}$. The flow rate was $0.2 \mathrm{~mL} / \mathrm{min}$, the column temperature was $40^{\circ} \mathrm{C}$, and the injection volume was $3 \mu \mathrm{L}$. the ion source was the AJS (Positive mode). Other conditions were as described above.

\subsection{Statistical Analyses}

The mean and SD of each value were calculated. In incubation with S9, the CTVD concentration and metabolite generation rate in humans and swine were analyzed using Student's $t$-test or Welch's test. $p$ values of $<0.05$ were considered to indicate statistical significance. All statistical analyses were performed using R version 3.5 .0 (2018-04-23) (R Core Team [2018]. R: A language and environment for statistical computing. R Foundation for Statistical Computing, Vienna, Austria. available from: https://www.R-project.org/).

Author Contributions: Conceptualization, Y.U. and Y.S.-K.; methodology, Y.U., M.N., N.S., N.K. and Y.S.-K.; investigation, Y.U. and M.N.; formal analysis, Y.U. and M.T.; writing—original draft preparation, Y.U., N.K. and Y.S.-K.; writing-review and editing, all authors contributed to writing and reviewing the paper.

Funding: This research was by the Health and Labour Sciences Research Grants (Research on Food Safety, H28-shokuhin-ippan-004) from the Ministry of Health, Labour and Welfare of Japan.

Acknowledgments: We thank Sekimoto, Laboratory of Environmental Hygiene, Department of Environmental Science, School of Life and Environmental Science, Azabu University, for advice to S9 study. We are grateful to Fukuyama, Laboratory of veterinary pharmacology, Department of Veterinary Medicine, Azabu University, for advice to toxicokinetics study.

Conflicts of Interest: The authors declare no conflict of interest in association with the present study.

\section{Appendix A}

Table A1. Information of mass spectrum for each metabolite.

\begin{tabular}{ccccc}
\hline Metabolites & $\begin{array}{c}\text { Retention Time } \\
(\mathbf{m i n})\end{array}$ & Polarity & Base Peak Ion & Mass Accuracy \\
\cline { 5 - 5 } & 25.10 & Positive & $(\mathrm{M}+\mathrm{H})^{+}$ & 2.9 \\
$\begin{array}{c}\text { Hydroxylation and } \\
\text { methylation }\end{array}$ & 25.79 & Positive & $(\mathrm{M}+\mathrm{H})^{+}$ & 1.1 \\
$\begin{array}{c}\text { Desaturation } \\
\text { Dihydroxylation }\end{array}$ & 22.57 & Positive & $(\mathrm{M}+\mathrm{H})^{+}$ & 3.1 \\
\hline
\end{tabular}

Table A2. The database of predicted metabolites of CTVD.

\begin{tabular}{|c|c|c|c|c|c|}
\hline Name & $\begin{array}{l}\text { Chemical } \\
\text { Formula }\end{array}$ & Exact Mass & Name & $\begin{array}{l}\text { Chemical } \\
\text { Formula }\end{array}$ & $\begin{array}{l}\text { Exact } \\
\text { Mass }\end{array}$ \\
\hline$(\mathrm{O}, \mathrm{N}, \mathrm{S})$ Methylation & $\mathrm{C}_{24} \mathrm{H}_{32} \mathrm{O}_{6}$ & 416.21989 & $\begin{array}{c}\text { Ethyl to Carboxylic } \\
\text { Acid }\end{array}$ & $\mathrm{C}_{22} \mathrm{H}_{26} \mathrm{O}_{8}$ & 418.16277 \\
\hline $\begin{array}{c}\text { 1,4-Dihydropyridines to } \\
\text { Pyridines }\end{array}$ & $\mathrm{C}_{23} \mathrm{H}_{28} \mathrm{O}_{6}$ & 400.18859 & $\begin{array}{c}\text { First/Second } \\
\text { Alcohols to } \\
\text { Aldehyde/Ketone }\end{array}$ & $\mathrm{C}_{23} \mathrm{H}_{28} \mathrm{O}_{6}$ & 400.18859 \\
\hline 2-Ethoxyl to Acid & $\mathrm{C}_{22} \mathrm{H}_{26} \mathrm{O}_{7}$ & 402.16785 & $\begin{array}{l}\text { Glucuronidation + } \\
\text { Hydrogenation }\end{array}$ & $\mathrm{C}_{29} \mathrm{H}_{40} \mathrm{O}_{12}$ & 580.25198 \\
\hline $\begin{array}{l}2 \times \text { Glucuronide } \\
\text { Conjugation }\end{array}$ & $\mathrm{C}_{35} \mathrm{H}_{46} \mathrm{O}_{18}$ & 754.26841 & $\begin{array}{l}\text { Glucuronide } \\
\text { Conjugation }\end{array}$ & $\mathrm{C}_{29} \mathrm{H}_{38} \mathrm{O}_{12}$ & 578.23633 \\
\hline $2 \times$ Hydrogenation & $\mathrm{C}_{23} \mathrm{H}_{34} \mathrm{O}_{6}$ & 406.23554 & $\begin{array}{l}\text { Glutamine } \\
\text { Conjugation }\end{array}$ & $\mathrm{C}_{28} \mathrm{H}_{38} \mathrm{NO}_{8}$ & 516.25974 \\
\hline $\begin{array}{c}2 \times \text { Hydroxylation and } \\
\text { Sulfation }\end{array}$ & $\mathrm{C}_{23} \mathrm{H}_{30} \mathrm{O}_{14} \mathrm{~S}_{2}$ & 594.10770 & $\begin{array}{l}\text { Gluthation } \\
\text { Conjugation } \\
\text { Gluthation }\end{array}$ & $\mathrm{C}_{33} \mathrm{H}_{47} \mathrm{~N}_{3} \mathrm{O}_{12} \mathrm{~S}$ & 709.28804 \\
\hline $2 \times$ Hydroxylation & $\mathrm{C}_{23} \mathrm{H}_{30} \mathrm{O}_{8}$ & 434.19407 & $\begin{array}{l}\text { Conjugation + } \\
\text { Demethylation }\end{array}$ & $\mathrm{C}_{32} \mathrm{H}_{43} \mathrm{~N}_{3} \mathrm{O}_{12} \mathrm{~S}$ & 693.25674 \\
\hline
\end{tabular}


Table A2. Cont.

\begin{tabular}{|c|c|c|c|c|c|}
\hline Name & $\begin{array}{l}\text { Chemical } \\
\text { Formula }\end{array}$ & Exact Mass & Name & $\begin{array}{l}\text { Chemical } \\
\text { Formula }\end{array}$ & $\begin{array}{l}\text { Exact } \\
\text { Mass }\end{array}$ \\
\hline $\begin{array}{l}2 \times \text { Hydroxylation }+2 \times \\
\text { Glucuronide }\end{array}$ & $\mathrm{C}_{35} \mathrm{H}_{46} \mathrm{O}_{20}$ & 786.25824 & $\begin{array}{c}\text { Gluthation } \\
\text { Conjugation }+ \\
\text { Dihydroxylation }\end{array}$ & $\mathrm{C}_{33} \mathrm{H}_{45} \mathrm{~N}_{3} \mathrm{O}_{14} \mathrm{~S}$ & 739.26222 \\
\hline $\begin{array}{l}2 \times \text { Oxidation }+ \\
\text { Glucuronidation }\end{array}$ & $\mathrm{C}_{29} \mathrm{H}_{38} \mathrm{O}_{14}$ & 610.22616 & $\begin{array}{l}\text { Gluthation } \\
\text { Conjugation + } \\
\text { Hydroxylation } \\
\text { Gluthation }\end{array}$ & $\mathrm{C}_{33} \mathrm{H}_{45} \mathrm{~N}_{3} \mathrm{O}_{13} \mathrm{~S}$ & 723.26731 \\
\hline $2 \times$ Sulfate Conjugation & $\mathrm{C}_{23} \mathrm{H}_{30} \mathrm{O}_{12} \mathrm{~S}_{2}$ & 562.11787 & $\begin{array}{l}\text { Conjugation, } \\
\text { Hydroxylation }+ \\
\text { Oxidation }\end{array}$ & $\mathrm{C}_{33} \mathrm{H}_{43} \mathrm{~N}_{3} \mathrm{O}_{14} \mathrm{~S}$ & 737.24657 \\
\hline $3 \times$ Hydroxylation & $\mathrm{C}_{23} \mathrm{H}_{30} \mathrm{O}_{9}$ & 450.18898 & Glycine Conjugation & $\mathrm{C}_{25} \mathrm{H}_{33} \mathrm{NO}_{7}$ & 459.22570 \\
\hline $\begin{array}{l}3 \times \text { Oxidation }+ \\
\text { Dehydrogenation }\end{array}$ & $\mathrm{C}_{23} \mathrm{H}_{28} \mathrm{O}_{9}$ & 448.17333 & $\begin{array}{c}\text { Hetero oxide } \\
\text { reduction }+ \\
\text { Hydrogenation }\end{array}$ & $\mathrm{C}_{23} \mathrm{H}_{32} \mathrm{O}_{5}$ & 388.22497 \\
\hline Acetylation & $\mathrm{C}_{25} \mathrm{H}_{32} \mathrm{O}_{7}$ & 444.21480 & $\begin{array}{c}\text { Hydration, } \\
\text { Hydrolysis (Internal) }\end{array}$ & $\mathrm{C}_{23} \mathrm{H}_{32} \mathrm{O}_{7}$ & 420.21480 \\
\hline Acetylation + Oxidation & $\mathrm{C}_{25} \mathrm{H}_{32} \mathrm{O}_{8}$ & 460.20972 & Hydrogenation & $\mathrm{C}_{23} \mathrm{H}_{32} \mathrm{O}_{6}$ & 404.21989 \\
\hline Alcohols Dehydration & $\mathrm{C}_{23} \mathrm{H}_{28} \mathrm{O}_{5}$ & 384.19367 & $\begin{array}{l}\text { Hydrolysis }+2 \times \\
\text { Oxidation }\end{array}$ & $\mathrm{C}_{23} \mathrm{H}_{32} \mathrm{O}_{9}$ & 452.20463 \\
\hline Alkene to Epoxide & $\mathrm{C}_{23} \mathrm{H}_{30} \mathrm{O}_{7}$ & 418.19915 & Hydroxylation & $\mathrm{C}_{23} \mathrm{H}_{30} \mathrm{O}_{7}$ & 418.19915 \\
\hline Alkenes to Dihydrodiol & $\mathrm{C}_{23} \mathrm{H}_{32} \mathrm{O}_{8}$ & 436.20972 & $\begin{array}{l}\text { Hydroxylation + } \\
\text { Glucuronide }\end{array}$ & $\mathrm{C}_{29} \mathrm{H}_{38} \mathrm{O}_{13}$ & 594.23124 \\
\hline Aromatic Oxidation & $\mathrm{C}_{24} \mathrm{H}_{32} \mathrm{O}_{8}$ & 448.20972 & $\begin{array}{l}\text { Hydroxylation and } \\
\text { Dehydration }\end{array}$ & $\mathrm{C}_{23} \mathrm{H}_{28} \mathrm{O}_{6}$ & 400.18859 \\
\hline $\begin{array}{c}\text { Aromatic Ring to Arene } \\
\text { Oxide }\end{array}$ & $\mathrm{C}_{23} \mathrm{H}_{30} \mathrm{O}_{7}$ & 418.19915 & $\begin{array}{l}\text { Hydroxylation and } \\
\text { Desaturation }\end{array}$ & $\mathrm{C}_{23} \mathrm{H}_{28} \mathrm{O}_{7}$ & 416.18350 \\
\hline $\begin{array}{l}\text { Carboxylation + } \\
\text { Glucuronidation }\end{array}$ & $\mathrm{C}_{29} \mathrm{H}_{36} \mathrm{O}_{14}$ & 608.21051 & $\begin{array}{l}\text { Hydroxylation and } \\
\text { Ketone Formation }\end{array}$ & $\mathrm{C}_{23} \mathrm{H}_{28} \mathrm{O}_{8}$ & 432.17842 \\
\hline Cysteine Conjugation & $\mathrm{C}_{26} \mathrm{H}_{37} \mathrm{NO}_{8} \mathrm{~S}$ & 523.22399 & $\begin{array}{l}\text { Hydroxylation and } \\
\text { Methylation }\end{array}$ & $\mathrm{C}_{24} \mathrm{H}_{32} \mathrm{O}_{7}$ & 432.21480 \\
\hline $\begin{array}{c}\text { Cysteine Conjugation and } \\
\text { Desaturation }\end{array}$ & $\mathrm{C}_{26} \mathrm{H}_{35} \mathrm{NO}_{8} \mathrm{~S}$ & 521.20834 & $\begin{array}{l}\text { Hydroxylation and } \\
\text { Sulfation }\end{array}$ & $\mathrm{C}_{23} \mathrm{H}_{30} \mathrm{O}_{10} \mathrm{~S}$ & 498.15597 \\
\hline $\begin{array}{l}\text { Cysteine Glycine } \\
\text { Conjugation }\end{array}$ & $\mathrm{C}_{28} \mathrm{H}_{40} \mathrm{~N}_{2} \mathrm{O}_{9} \mathrm{~S}$ & 580.24545 & $\begin{array}{l}\text { Hydroxymethylene } \\
\text { Loss }\end{array}$ & $\mathrm{C}_{22} \mathrm{H}_{28} \mathrm{O}_{5}$ & 372.19367 \\
\hline $\begin{array}{l}\text { Cysteine Glycine } \\
\text { Conjugation and } \\
\text { Desaturation }\end{array}$ & $\mathrm{C}_{28} \mathrm{H}_{38} \mathrm{~N}_{2} \mathrm{O}_{9} \mathrm{~S}$ & 578.22980 & $\begin{array}{c}\text { Isopropyl } \\
\text { Dealkylation }\end{array}$ & $\mathrm{C}_{20} \mathrm{H}_{24} \mathrm{O}_{6}$ & 360.15729 \\
\hline Deacetylation & $\mathrm{C}_{21} \mathrm{H}_{28} \mathrm{O}_{5}$ & 360.19367 & Isopropyl to Acid & $\mathrm{C}_{21} \mathrm{H}_{24} \mathrm{O}_{8}$ & 404.14712 \\
\hline $\begin{array}{c}\text { Dacetylation + } \\
\text { Dehydrogenation }\end{array}$ & $\mathrm{C}_{21} \mathrm{H}_{26} \mathrm{O}_{5}$ & 358.17802 & Isopropyl to Alcohol & $\mathrm{C}_{20} \mathrm{H}_{24} \mathrm{O}_{7}$ & 376.15220 \\
\hline Debenzylation & $\mathrm{C}_{16} \mathrm{H}_{24} \mathrm{O}_{6}$ & 312.15729 & Ketone to Alcohol & $\mathrm{C}_{23} \mathrm{H}_{32} \mathrm{O}_{6}$ & 404.21989 \\
\hline $\begin{array}{l}\text { Debutylation + } \\
\text { Hydrogenation }\end{array}$ & $\mathrm{C}_{19} \mathrm{H}_{24} \mathrm{O}_{6}$ & 348.15729 & $\begin{array}{c}\text { Methyl Ketone to } \\
\text { Acid }\end{array}$ & $\mathrm{C}_{21} \mathrm{H}_{26} \mathrm{O}_{7}$ & 390.16785 \\
\hline Decarbonylation & $\mathrm{C}_{22} \mathrm{H}_{30} \mathrm{O}_{5}$ & 374.20932 & Methylene to Ketone & $\mathrm{C}_{23} \mathrm{H}_{28} \mathrm{O}_{7}$ & 416.18350 \\
\hline Decarboxylation & $\mathrm{C}_{22} \mathrm{H}_{30} \mathrm{O}_{4}$ & 358.21441 & $\begin{array}{l}\text { N-Acethylcysteine } \\
\text { Conjugation }\end{array}$ & $\mathrm{C}_{28} \mathrm{H}_{39} \mathrm{NO}_{9} \mathrm{~S}$ & 565.23455 \\
\hline $\begin{array}{l}\text { Decarboxylation and } \\
\text { Glucuronidation }\end{array}$ & $\mathrm{C}_{28} \mathrm{H}_{38} \mathrm{O}_{11}$ & 550.24141 & $\begin{array}{l}\text { N-Acethylcysteine } \\
\text { Conjugation and } \\
\text { Desaturation }\end{array}$ & $\mathrm{C}_{28} \mathrm{H}_{37} \mathrm{NO}_{9} \mathrm{~S}$ & 563.21890 \\
\hline Deethylation & $\mathrm{C}_{21} \mathrm{H}_{26} \mathrm{O}_{6}$ & 374.17294 & $\begin{array}{l}\text { Oxidation }+2 \times \\
\text { Desaturation }\end{array}$ & $\mathrm{C}_{23} \mathrm{H}_{26} \mathrm{O}_{7}$ & 414.16785 \\
\hline Demethylation & $\mathrm{C}_{22} \mathrm{H}_{28} \mathrm{O}_{6}$ & 388.18859 & $\begin{array}{c}\text { Oxidation }+ \\
\text { Acethylcysteination }\end{array}$ & $\mathrm{C}_{28} \mathrm{H}_{39} \mathrm{NO}_{10} \mathrm{~S}$ & 581.22947 \\
\hline $\begin{array}{l}\text { Demethylation }+ \\
\text { Dehydrogenation }\end{array}$ & $\mathrm{C}_{22} \mathrm{H}_{26} \mathrm{O}_{6}$ & 386.17294 & $\begin{array}{c}\text { Oxidation }+ \\
\text { Deacetylation }\end{array}$ & $\mathrm{C}_{21} \mathrm{H}_{28} \mathrm{O}_{6}$ & 376.18859 \\
\hline $\begin{array}{l}\text { Demethylation + } \\
\text { Glucuronidation }\end{array}$ & $\mathrm{C}_{28} \mathrm{H}_{36} \mathrm{O}_{12}$ & 564.22068 & $\begin{array}{c}\text { Oxidation }+ \\
\text { Demethylation }+ \\
\text { Dehydrogenation }\end{array}$ & $\mathrm{C}_{22} \mathrm{H}_{26} \mathrm{O}_{7}$ & 402.16785 \\
\hline
\end{tabular}


Table A2. Cont.

\begin{tabular}{|c|c|c|c|c|c|}
\hline Name & $\begin{array}{l}\text { Chemical } \\
\text { Formula }\end{array}$ & Exact Mass & Name & $\begin{array}{l}\text { Chemical } \\
\text { Formula }\end{array}$ & $\begin{array}{l}\text { Exact } \\
\text { Mass }\end{array}$ \\
\hline $\begin{array}{l}\text { Demethylation }+ \\
\text { Hydrogenation }\end{array}$ & $\mathrm{C}_{22} \mathrm{H}_{30} \mathrm{O}_{6}$ & 390.20424 & Parent & $\mathrm{C}_{23} \mathrm{H}_{30} \mathrm{O}_{6}$ & 402.20424 \\
\hline $\begin{array}{l}\text { Demethylation }+ \\
\text { Oxidation }+ \\
\text { Glucuronidation }\end{array}$ & $\mathrm{C}_{28} \mathrm{H}_{36} \mathrm{O}_{13}$ & 580.21559 & Phosphorylation & $\mathrm{C}_{23} \mathrm{H}_{31} \mathrm{O}_{9} \mathrm{P}$ & 482.17057 \\
\hline $\begin{array}{l}\text { Demethylation and } \\
\text { Hydroxylation }\end{array}$ & $\mathrm{C}_{22} \mathrm{H}_{28} \mathrm{O}_{7}$ & 404.18350 & Propyl Ether to Acid & $\mathrm{C}_{20} \mathrm{H}_{22} \mathrm{O}_{7}$ & 374.13655 \\
\hline $\begin{array}{l}\text { Demethylation and } \\
\text { Methylene to Ketone }\end{array}$ & $\mathrm{C}_{22} \mathrm{H}_{26} \mathrm{O}_{7}$ & 402.16785 & $\begin{array}{c}\text { Propyl Ketone to } \\
\text { Acid }\end{array}$ & $\mathrm{C}_{19} \mathrm{H}_{22} \mathrm{O}_{7}$ & 362.13655 \\
\hline $\begin{array}{l}\text { Demethylation and two } \\
\text { Hydroxylations }\end{array}$ & $\mathrm{C}_{22} \mathrm{H}_{28} \mathrm{O}_{8}$ & 420.17842 & Quinone Formation & $\mathrm{C}_{23} \mathrm{H}_{28} \mathrm{O}_{8}$ & 432.17842 \\
\hline $\begin{array}{l}\text { Demethylation to } \\
\text { Carboxylic Acid }\end{array}$ & $\mathrm{C}_{23} \mathrm{H}_{28} \mathrm{O}_{8}$ & 432.17842 & Sulfate Conjugation & $\mathrm{C}_{23} \mathrm{H}_{30} \mathrm{O}_{9} \mathrm{~S}$ & 482.16105 \\
\hline Desaturation & $\mathrm{C}_{23} \mathrm{H}_{28} \mathrm{O}_{6}$ & 400.18859 & Taurine Conjugation & $\mathrm{C}_{25} \mathrm{H}_{35} \mathrm{NO}_{8} \mathrm{~S}$ & 509.20834 \\
\hline $\begin{array}{c}\text { Desaturation }+ \\
\text { Gluthation Conjugation }\end{array}$ & $\mathrm{C}_{33} \mathrm{H}_{45} \mathrm{~N}_{3} \mathrm{O}_{12} \mathrm{~S}$ & 707.27239 & $\begin{array}{c}\text { Tert-Butyl } \\
\text { Dealkylation }\end{array}$ & $\mathrm{C}_{19} \mathrm{H}_{22} \mathrm{O}_{6}$ & 346.14164 \\
\hline $\begin{array}{c}\text { Epoxidation + Gluthation } \\
\text { Conjugation }\end{array}$ & $\mathrm{C}_{33} \mathrm{H}_{47} \mathrm{~N}_{3} \mathrm{O}_{13} \mathrm{~S}$ & 725.28296 & Tert-Butyl to Acid & $\mathrm{C}_{20} \mathrm{H}_{22} \mathrm{O}_{8}$ & 390.13147 \\
\hline $\begin{array}{l}\text { Ethyl Ether to Acid } \\
\text { Ethyl Ketone to Acid }\end{array}$ & $\begin{array}{l}\mathrm{C}_{21} \mathrm{H}_{24} \mathrm{O}_{7} \\
\mathrm{C}_{20} \mathrm{H}_{24} \mathrm{O}_{7}\end{array}$ & $\begin{array}{l}388.15220 \\
376.15220\end{array}$ & $\begin{array}{l}\text { Tert-Butyl to Alcohol } \\
\text { Triphosphorylation }\end{array}$ & $\begin{array}{c}\mathrm{C}_{19} \mathrm{H}_{22} \mathrm{O}_{7} \\
\mathrm{C}_{23} \mathrm{H}_{33} \mathrm{O}_{15} \mathrm{P}_{3}\end{array}$ & $\begin{array}{l}362.13655 \\
642.10323\end{array}$ \\
\hline Ethyl to Alcohol & $\mathrm{C}_{21} \mathrm{H}_{26} \mathrm{O}_{7}$ & 390.16785 & $\begin{array}{l}\text { Two Sequential } \\
\text { Desaturations }\end{array}$ & $\mathrm{C}_{23} \mathrm{H}_{26} \mathrm{O}_{6}$ & 398.17294 \\
\hline
\end{tabular}

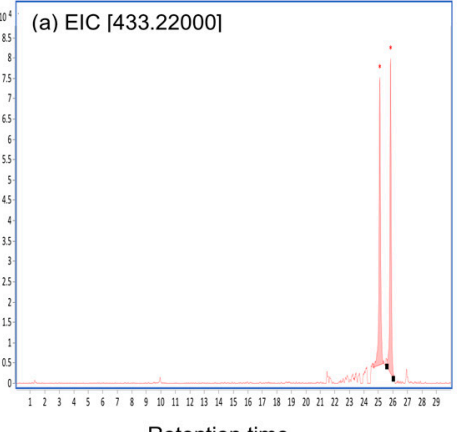

Retention time

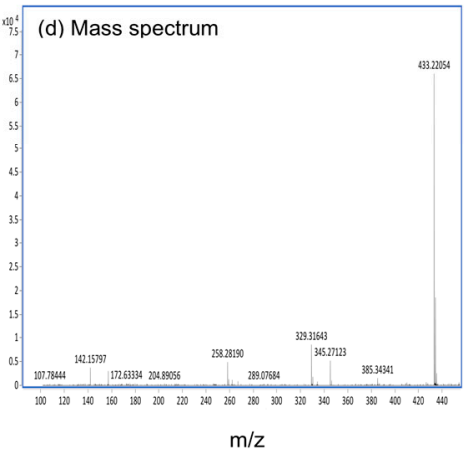

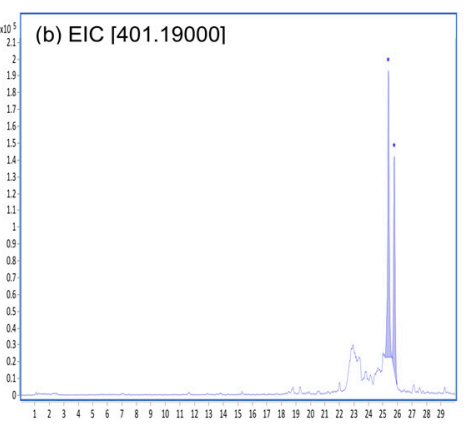

Retention time

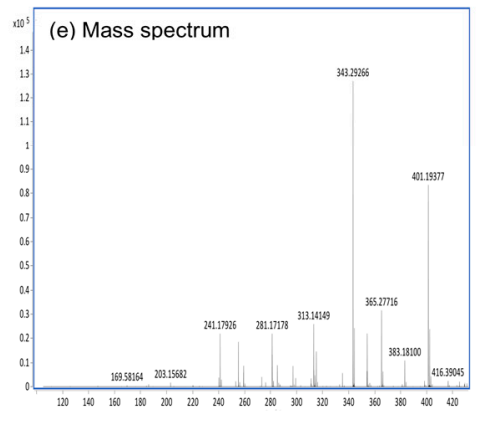

$\mathrm{m} / \mathrm{z}$

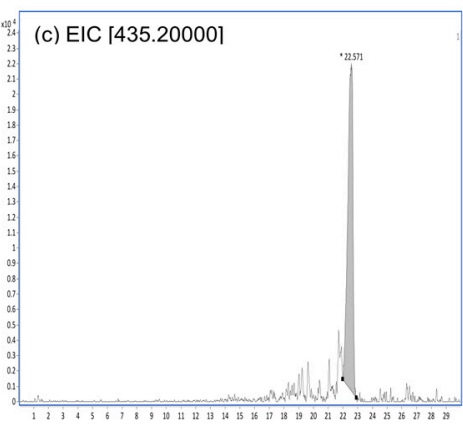

Retention time

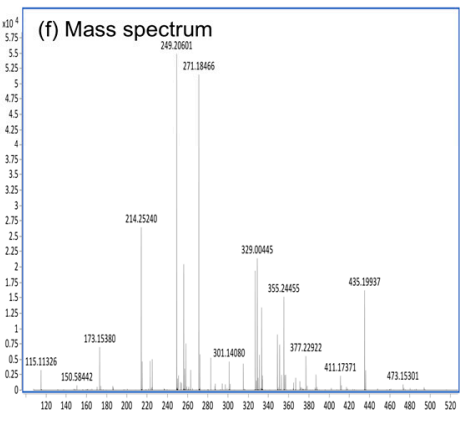

$\mathrm{m} / \mathrm{z}$

Figure A1. The extracted ion chromatogram (EIC) and mass spectra of the main metabolites of CTVD incubated with S9. The EIC and mass spectra were analyzed by Q-TOF. The compounds presumably produced by incubation with S9 fractions supplemented with NADP were as follows: (a-c) represent the EIC of hydroxylation and methylation (EIC 433.22000), desaturation (EIC 401.19000), and dihydroxylation (EIC 435.20000), respectively, at $240 \mathrm{~min}$ after incubation with swine hepatic S9. (d-f) represent their mass spectra. 

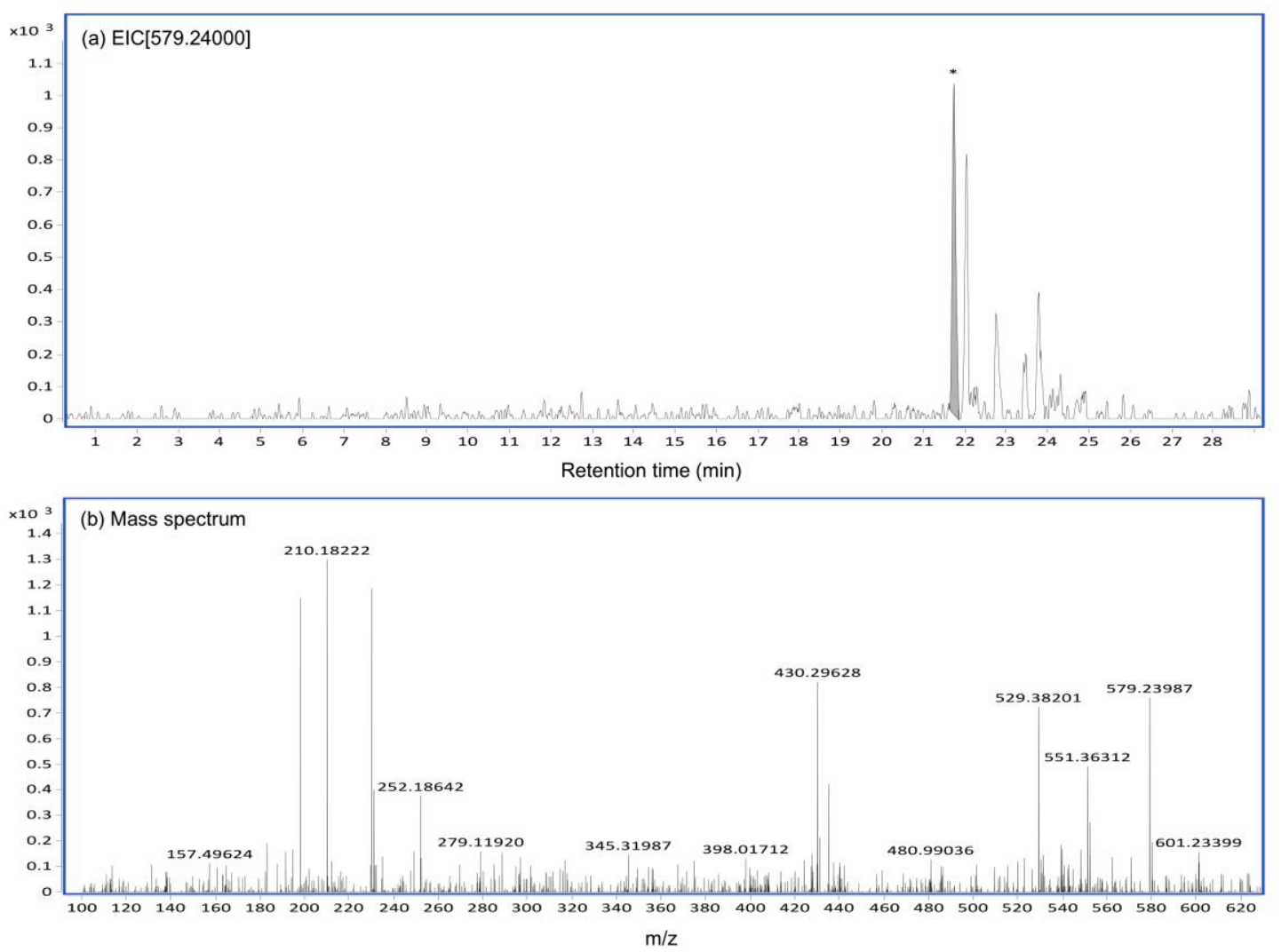

Figure A2. The EIC and mass spectrum of CTVD glucuronide generated by incubation with S9 including UDPGA. The EIC and mass spectrum of CTVD glucuronide produced by incubation with swine hepatic S9 supplemented with UDPGA were analyzed by Q-TOF. The EIC (a) and mass spectrum (b) of CTVD glucuronide as observed at $240 \mathrm{~min}$ after incubation with swine hepatic S9.

\section{References}

1. Lima, H.C.A.V.; Porto, E.A.S.; Marins, J.R.P.; Alves, R.M.; Machado, R.R.; Braga, K.N.L.; de Paiva, B.; Carmo, G.M.I.; Faria Silva e Santelli, A.C.; Sobel, J. Outbreak of beriberi in the state of Maranhão, Brazil: Revisiting the mycotoxin aetiologic hypothesis. Trop. Dr. 2010, 40, 95-97. [CrossRef] [PubMed]

2. Cole, R.J.; Dorner, J.W.; Cox, R.H.; Hill, R.A.; Cluter, H.G.; Wells, J.M. Isolation of citreoviridin from Penicillium charlesii cultures and molded pecan fragments. Appl. Environ. Microbiol. 1981, 42, 677-681. [PubMed]

3. Wicklow, D.T.; Cole, R.J. Citreoviridin in standing corn infested by Eupenicillium ochrosalmoneum. Mycologia 1984, 76, 959-961. [CrossRef]

4. Wicklow, D.T.; Stubblefield, R.D.; Horn, B.W.; Shotwell, O.L. Citreoviridin levels in Eupenicillium ochrosalmoneum-infested maize kernels at harvest. Appl. Environ. Microbiol. 1988, 54, 1096-1098. [PubMed]

5. Almeida, M.I.; Almeida, N.G.; Carvalho, K.L.; Gonçalves, G.A.A.; Silva, C.N.; Santos, E.A.; Garcia, J.C.; Vargas, E.A. Co-occurrence of aflatoxins B1, B2, G1 and G2, ochratoxin A, zearalenone, deoxynivalenol, and citreoviridin in rice in Brazil. Food Addit. Contam. Part A 2012, 29, 694-703. [CrossRef]

6. Shiratori, N.; Kobayashi, N.; Tulayakul, P.; Sugiura, Y.; Takino, M.; Endo, O.; Sugita-Konishi, Y. Occurrence of Penicillium brocae and Penicillium citreonigrum, which produce a mutagenic metabolite and a mycotoxin citreoviridin, respectively, in selected commercially available rice grains in Thailand. Toxins 2017, 9, 194. [CrossRef]

7. Kushiro, M. Historical review of researches on yellow rice and mycotoxigenic fungi adherent to rice in Japan. JSM Mycotoxins 2015, 65, 19-23. [CrossRef]

8. Ueno, Y. Temperature-dependent production of citreoviridin, a neurotoxin of Penicillium citreo-viride Biourge. Jpn. J. Exp. Med. 1972, 42, 107-114. 
9. Padilha, E.M.; Fujimori, E.; Borges, A.L.; Sato, A.P.; Gomes, M.N.; Branco, M.R.; Santos, H.J.; Lermen, N., Jr. Epidemiological profile of reported beriberi cases in Maranhão State, Brazil, 2006-2008. Cad. Saude Publica 2011, 27, 449-459. [CrossRef]

10. Rosa, C.A.R.; Keller, K.M.; Oliveira, A.A.; Almeida, T.X.; Keller, L.A.M.; Marassi, A.C.; Kruger, C.D.; Deveza, M.V.; Monteiro, B.S.; Nunes, L.M.T.; et al. Production of citreoviridin by Penicillium citreonigrum strains associated with rice consumption and beriberi cases in the Maranhão State, Brazil. Food Addit. Contam. A 2010, 27, 241-248. [CrossRef]

11. Uraguchi, K. Mycotoxic origin of cardiac beriberi. J. Stored Prod. Res. 1969, 5, 227-236. [CrossRef]

12. Ueno, Y.; Ueno, I. Isolation and acute toxicity of citreoviridin, a neurotoxic mycotoxin of Penicillium citreo-viride Biourge. Jpn. J. Exp. Med. 1972, 42, 91-105. [PubMed]

13. Ueno, Y. Citreoviridin from Penicillium citreoviride Biourge. In Mycotoxins; Purchase, I.F.H., Ed.; Elsevier Scientific Publ. Co.: New York, NY, USA, 1974; pp. 283-302.

14. Nishie, K.; Cole, R.J.; Dorner, J.W. Toxicity of citreoviridin. Res. Commun. Chem. Pathol. Pharmacol. 1988, 59, 31-52. [PubMed]

15. Uraguchi, K. Evidence of a toxin in the yellowed rice polluted by Penicillium sp. Pharmacological studies on the toxicity of the yellowed rice "O-hen mai" I. Nisshin. Igaku 1947, 34, 155-161.

16. Sakai, F.; Uraguchi, K. Studies by long-term feeding experiments with rats on development of chronic poisoning by toxic substance from yellowsis rice. VII. Pharmacological studies on toxicity of yellowsis rice. Nisshin. Igaku 1955, 42, 609-617.

17. Sun, S. Chronic exposure to cereal mycotoxin likely citreoviridin may be a trigger for Keshan disease mainly through oxidative stress mechanism. Med. Hypotheses 2010, 74, 841-842. [CrossRef]

18. Lau, Y.Y.; Chen, Y.H.; Liu, T.T.; Li, C.; Cui, X.; White, R.E.; Cheng, K.C. Evaluation of a novel in vitro Caco-2 hepatocyte hybrid system for predicting in vivo oral bioavailability. Drug Metab. Dispos. 2004, 32, 937-942.

19. Li, C.; Liu, T.; Cui, X.; Uss, A.S.; Cheng, K.C. Development of in vitro pharmacokinetic screens using Caco-2, human hepatocyte, and Caco-2/human hepatocyte hybrid systems for the prediction of oral bioavailability in humans. J. Biomol. Screen. 2007, 12, 1084-1091.

20. Srinivasan, B.; Kolli, A.R.; Esch, M.B.; Abaci, H.E.; Shuler, M.L.; Hickman, J.J. TEER measurement techniques for in vitro barrier model systems. J. Lab. Autom. 2015, 20, 107-126. [CrossRef]

21. Kadota, T.; Furusawa, H.; Hirano, S.; Tajima, O.; Kamata, Y.; Sugita-Konishi, Y. Comparative study of deoxynivalenol, 3-acetyldeoxynivalenol, and 15-acetyldeoxynivalenol on intestinal transport and IL-8 secretion in the human cell line Caco-2. Toxicol. In Vitro 2013, 27, 1888-1895. [CrossRef]

22. Jaeg, J.P.; Perdu, E.; Dolo, L.; Debrauwer, L.; Cravedi, J.P.; Zalko, D. Characterization of new bisphenol A metabolites produced by CD1 mice liver microsomes and S9 fractions. J. Agric. Food Chem. 2004, 52, 4935-4942. [CrossRef] [PubMed]

23. Mortensen, B.; Løkken, T.; Zahlsen, K.; Nilsen, O.G. Comparison and in vivo relevance of two different in vitro head space metabolic systems: Liver S9 and liver slices. Pharmacol. Toxicol. 1997, 81, 35-41. [CrossRef] [PubMed]

24. Wu, W.N.; McKown, L.A. In Vitro Drug Metabolite Profiling Using Hepatic S9 and Human Liver Microsomes. In Optimization in Drug Discovery; Yan, Z., Caldwell, G.W., Eds.; Humana Press: New York, NY, USA, 2004; pp. 163-184.

25. Merrifield, C.A.; Lewis, M.; Claus, S.P.; Beckonert, O.P.; Dumas, M.E.; Duncker, S.; Kochhar, S.; Rezzi, S.; Lindon, J.C.; Bailey, M.; et al. A metabolic system-wide characterisation of the pig: A model for human physiology. Mol. Biosyst. 2011, 7, 2577-2588. [CrossRef] [PubMed]

26. Tanaka, S.; Oyama, M.; Nishikawa, M.; Ikushiro, S.; Hara, H. Simultaneous collection of the portal and superior vena cava blood in conscious rats defined that intestinal epithelium is the major site of glucuronidation, but not sulfation and methylation, of quercetin. Biosci. Biotechnol. Biochem. 2018, 82, 2118-2129. [CrossRef] [PubMed]

27. Goyarts, T.; Dänicke, S. Bioavailability of the Fusarium toxin deoxynivalenol (DON) from naturally contaminated wheat for the pig. Toxicol. Lett. 2006, 163, 171-182. [CrossRef] [PubMed]

28. Prelusky, D.B.; Hartin, K.E.; Trenholm, H.L.; Miller, J.D. Pharmacokinetic fate of 14C-labeled deoxynivalenol in swine. Toxicol. Sci. 1988, 10, 276-286. [CrossRef]

29. Rohweder, D.; Kersten, S.; Valenta, H.; Sondermann, S.; Schollenberger, M.; Drochner, W.; Dänicke, S. Bioavailability of the Fusarium toxin deoxynivalenol (DON) from wheat straw and chaff in pigs. Arch. Anim. Nutr. 2013, 67, 37-47. [CrossRef] 
30. Galtier, P.; Alvinerie, M.; Charpenteau, J.L. The pharmacokinetic profiles of ochratoxin A in pigs, rabbits and chickens. Food Cosmet. Toxicol. 1981, 19, 735-738. [CrossRef]

31. Biehl, M.L.; Prelusky, D.B.; Koritz, G.D.; Hartin, K.E.; Buck, W.B.; Trenholm, H.L. Biliary excretion and enterohepatic cycling of zearalenone in immature pigs. Toxicol. Appl. Pharmacol. 1993, 121, 152-159. [CrossRef]

32. Yiannikouris, A.; Jouany, J.P. Mycotoxins in feeds and their fate in animals: A review. Anim. Res. 2002, 51, 81-99. [CrossRef]

33. Charman, W.N.; Stella, V.J. Transport of lipophilic molecules by the intestinal lymphatic system. Adv. Drug Deliv. Rev. 1991, 7, 1-14. [CrossRef]

34. Artursson, P.E.R. Epithelial transport of drugs in cell culture. I: A model for studying the passive diffusion of drugs over intestinal absorbtive (Caco-2) cells. J. Pharm. Sci. 1990, 79, 476-482. [CrossRef] [PubMed]

35. Van De Walle, J.; Sergent, T.; Piront, N.; Toussaint, O.; Schneider, Y.J.; Larondelle, Y. Deoxynivalenol affects in vitro intestinal epithelial cell barrier integrity through inhibition of protein synthesis. Toxicol. Appl. Pharmacol. 2010, 245, 291-298. [CrossRef] [PubMed]

36. Pfeiffer, E.; Kommer, A.; Dempe, J.S.; Hildebrand, A.A.; Metzler, M. Absorption and metabolism of the mycotoxin zearalenone and the growth promotor zeranol in Caco-2 cells in vitro. Mol. Nutr. Food Res. 2011, 55, 560-567. [CrossRef] [PubMed]

37. Caloni, F.; Cortinovis, C.; Pizzo, F.; De Angelis, I. Transport of aflatoxin M1 in human intestinal Caco-2/TC7 cells. Front. Pharmacol. 2012, 3, 111. [CrossRef] [PubMed]

38. Leibholz, J. Digestion in the pig between 7 and $35 \mathrm{~d}$ of age 6 . The digestion of hydrolyzed milk and soya-bean proteins. Br. J. Nutr. 1981, 46, 59-69. [CrossRef] [PubMed]

39. Rychlik, M.; Kircher, F.; Schusdziarra, V.; Lippl, F. Absorption of the mycotoxin patulin from the rat stomach. Food Chem. Toxicol. 2004, 42, 729-735. [CrossRef] [PubMed]

40. Dänicke, S.; Valenta, H.; Döll, S. On the toxicokinetics and the metabolism of deoxynivalenol (DON) in the pig. Arch. Anim. Nutr. 2004, 58, 169-180. [CrossRef] [PubMed]

41. Baggot, J.D. Principles of Drug Disposition in Domestic Animals: The Basis of Veterinary Clinical Pharmacology; W.B. Saunders Co.: Philadelphia, PA, USA, 1977; pp. 114-145.

42. Hagelberg, S.; Hult, K.; Fuchs, R. Toxicokinetics of ochratoxin A in several species and its plasma-binding properties. J. Appl. Toxicol. 1989, 9, 91-96. [CrossRef]

43. Coulombe, R.A., Jr.; Sharma, R.P. Clearance and excretion of intratracheally and orally administered aflatoxin B1 in the rat. Food Chem. Toxicol. 1985, 23, 827-830. [CrossRef]

44. Prelusky, D.B.; Trenholm, H.L.; Savard, M.E. Pharmacokinetic fate of 14C-labelled fumonisin B1 in swine. Nat. Toxins 1994, 2, 73-80. [CrossRef] [PubMed]

45. Hou, H.; Qu, X.; Li, Y.; Kong, Y.; Jia, B.; Yao, X.; Jiang, B. Binding of citreoviridin to human serum albumin: Multispectroscopic and molecular docking. BioMed Res. Int. 2015, 2015. [CrossRef] [PubMed]

46. Stojković, R.; Hult, K.; Gamulin, S.; Plestina, R. High affinity binding of ochratoxin A to plasma constituents. Biochem. Int. 1984, 9, 33-38. [PubMed]

47. Kőszegi, T.; Poór, M. Ochratoxin A: Molecular interactions, mechanisms of toxicity and prevention at the molecular level. Toxins 2016, 8, 111. [CrossRef] [PubMed]

48. Maul, R.; Warth, B.; Kant, J.S.; Schebb, N.H.; Krska, R.; Koch, M.; Sulyok, M. Investigation of the hepatic glucuronidation pattern of the Fusarium mycotoxin deoxynivalenol in various species. Chem. Res. Toxicol. 2012, 25, 2715-2717. [CrossRef] [PubMed]

49. da Rocha, M.W.; Resck, I.S.; Caldas, E.D. Purification and full characterisation of citreoviridin produced by Penicillium citreonigrum in yeast extract sucrose (YES) medium. Food Addit. Contam. A 2015, 32, 584-595. [CrossRef] [PubMed]

50. Devreese, M.; De Baere, S.; De Backer, P.; Croubels, S. Quantitative determination of several toxicological important mycotoxins in pig plasma using multi-mycotoxin and analyte-specific high performance liquid chromatography-tandem mass spectrometric methods. J. Chromatogr. A 2012, 1257, 74-80. [CrossRef]

(C) 2019 by the authors. Licensee MDPI, Basel, Switzerland. This article is an open access article distributed under the terms and conditions of the Creative Commons Attribution (CC BY) license (http://creativecommons.org/licenses/by/4.0/). 